\title{
Population genetics of the endangered catfish Pseudoplatystoma magdaleniatum (Siluriformes: Pimelodidae) based on species-specific a microsatellite loci
}

\author{
Correspondence: \\ Edna Judith Márquez \\ ejmarque@unal.edu.co
}

Submitted October 26, 2020

Accepted February 17, 2021

by Claudio Oliveira Epub March 31, 2021

Online version ISSN 1982-0224 Print version ISSN 1679-6225

Neotrop. Ichthyol. vol. 19, no. 1, Maringá 2021

 \\ ${ }^{\circ}$ Ricardo Marcel Landínez-García ${ }^{1}$ and ${ }^{\bullet}$ Edna Judith Márquez ${ }^{1}$
}

The Neotropical catfish genus Pseudoplatystoma comprises eight species of large size, widely distributed in South American basins. The endangered species $P$. magdaleniatum is endemic to Magdalena basin (Colombia), experiences high fishing pressure and its population genetics is relatively unknown. To study the genetic status and structure of $P$. magdaleniatum, 25 species-specific polymorphic microsatellite loci were developed using next-generation sequencing and then tested in samples collected in the Magdalena-Cauca basin. Based on 15 of these loci, P. magdaleniatum showed a high number of alleles per locus (9-10), high values of observed (0.762-0.798) and expected (0.770-0.791) heterozygosities, recent reduction of population size and gene flow. These findings constitute a baseline to measure potential changes in genetic diversity and structure of this commercially important species in a basin undergoing high anthropogenic activities.

Keywords: Bottleneck, Freshwater fish, Gene flow, Genetic diversity, Molecular marker.

\footnotetext{
1 Facultad de Ciencias, Escuela de Biociencias, Laboratorio de Biología Molecular y Celular, Universidad Nacional de Colombia Sede Medellín. Carrera 65 No 59A - 110 Bloque 19 A Laboratorio 310, 050034 Medellín, Colombia. (KLGC) klgarciac@unal.edu.co; (JDRM) jdrangelm@unal.edu.co; (RMLG) rmlandin@unal.edu.co; (EJM) ejmarque@unal.edu.co (corresponding author).
} 
El género de bagres neotropicales Pseudoplatystoma comprende ocho especies de gran tamaño, ampliamente distribuidas en las cuencas de Suramérica. La especie en peligro de extinción P. magdaleniatum es endémica de la Cuenca del Magdalena (Colombia), experimenta una alta presión pesquera y su genética poblacional es relativamente desconocida. Para estudiar el estado y estructura genética de P. magdaleniatum, se desarrollaron 25 loci microsatélites polimórficos especie específicos utilizando secuenciación de próxima generación y se evaluaron en muestras recolectadas en la Cuenca del Magdalena-Cauca. Con base en 15 loci, P. magdaleniatum mostró un alto número de alelos por locus (9-10), valores altos de heterocigosidad observada $(0.762-0.798)$ y esperada $(0.770-0.791)$, reducción reciente del tamaño poblacional y flujo génico. Estos hallazgos constituyen una línea de base para medir cambios potenciales en la diversidad y estructura genética de esta especie comercialmente importante en una cuenca sometida a altas actividades antropogénicas.

Palabras clave: Cuello de botella, Diversidad genética, Flujo génico, Marcador molecular, Pez de agua dulce.

\section{INTRODUCTION}

The family Pimelodidae (long-whiskered catfishes) comprises 114 species of freshwater fishes widely distributed throughout the Neotropics, including some of the largest and most commercially valuable migratory catfish species (Fricke et al., 2020; Malabarba, Malabarba, 2020). The genus Pseudoplatystoma Bleeker, 1862 contains species that inhabits several of the main river basins of South America, can reach more than 1.3 $\mathrm{m}$ in length and have a strong commercial interest in fishery due to the high market demand of its meat (Buitrago-Suárez, 2006; Buitrago-Suárez, Burr, 2007; Reis et al., 2016). Pseudoplatystoma magdaleniatum Buitrago-Suárez \& Burr, 2007 (formerly Pseudoplatystoma fasciatum (Linnaeus, 1766)) is an endemic species, the largest migratory fish from Magdalena River basin (Zapata, Usma, 2013) and the most important fishery resource in Colombia behind Prochilodus magdalenae Steindachner, 1879 (bocachico) (Lasso et al., 2011; Zapata, Usma, 2013; Mojica et al., 2016).

According to the IUCN Red List (Mojica et al., 2016), P. magdaleniatum is currently categorized as endangered (EN) mainly due to heavy fishing pressure and other habitat threats related to livestocking, agriculture, mining and dam construction (Barletta et al., 2010; Angarita et al., 2018; Carranza-Lopez et al., 2019). Moreover, the current fishing regulations are solely based on information about the sexual maturity size and reproductive periods (Mojica et al., 2012; Álvarez-León, 2016) and little is known about the population genetics of this species, although this information is crucial for the development of effective management and preservation policies.

Microsatellites markers have been extensively used to investigate patterns of genetic structure and genetic variability at intra-specific level because of its high polymorphism and reproducibility (Guichoux et al., 2011; Fernandez-Silva et al., 2013). In Pseudoplatystoma, microsatellite loci have been developed for P. corruscans 
(Spix \& Agassiz, 1829), P. punctifer (Castelnau, 1855) and P. reticulatum Eigenmann \& Eigenmann, 1889 (Revaldaves et al., 2005; Pereira et al., 2009; Saulo-Machado et al., 2011; Prado et al., 2014), and crossed amplified in congeners to explore their structure and genetic diversity.

Previous population genetics studies in Pseudoplatystoma showed high levels of genetic diversity and significant genetic structure in P. corruscans from Paraguay and Paraná basins (Pereira et al., 2009; Vaini et al., 2016; Prado et al., 2018), and P. reticulatum from Paraguay basin (Abreu et al., 2009; Pereira et al., 2009). This genetic structure is explained by homing behavior (Pereira et al., 2009) or vicariant differentiation due to the presence of geographic accidents (Prado et al., 2018). Additionally, P. punctifer shows low levels of genetic differentiation in Brazilian Amazon (Telles et al., 2014), whereas $P$. reticulatum exhibits gene flow in Paraguay basin (Prado et al., 2018).

The genetic diversity and structure of $P$. magdaleniatum based on highly polymorphic loci remain unavailable so far. Thus, this study developed a set of species-specific microsatellite loci using next generation sequencing to evaluate the diversity and population structure of $P$. magdaleniatum in the Magdalena-Cauca basin. Considering the annual catch decrease, and anthropogenic habitat disturbances (Barletta et al., 2010; Mojica et al., 2012, 2016), the a priori expectation is to find populations with low genetic diversity and evidence of a recent reduction of population size. Additionally, evidence of gene flow is expected in this middle-distance migratory species given the absence of physical barriers throughout the sampling sites. The obtained information is crucial to support the development of proper management policies and provide a benchmark to monitor the genetic variability of this endangered species.

\section{MATERIAL AND METHODS}

Sampling. A total of 171 muscle tissues of P. magdaleniatum collected by Integral S.A. between 2011 and 2014 were submitted to genetic analysis (scientific cooperation agreement 19/09/2013, Grant CT-2013-002443, framed under an environmental license number 0155-30/01/2009 from Ministerio de Ambiente, Vivienda y Desarrollo Territorial de Colombia). Sampling corresponded to four sites (Fig. 1) previously described by Landínez-García, Márquez (2016) in the Cauca River: Margento (Section 5) and Punta Cartagena (Section 8), and Magdalena River (Puerto Berrío, Samaná Norte River).

Primers design, genotyping and polymorphism assessment of microsatellite loci. For primer design we used sequence reads previously obtained from a PairedEnd genomic library of one specimen of P. magdaleniatum, using the MiSeq Illumina platform (Rangel-Medrano et al., 2016). Bioinformatic procedures including selection of microsatellite regions and primers design as well as assessment of polymorphism of selected loci were conducted following Landínez-García, Márquez (2016).

Loci with tetranucleotide motifs were amplified using fluorescently labeled primers as detailed by Landínez-García, Márquez (2016), with some modifications in the final concentrations of the PCR mix $(0.5 \mathrm{pmol} / \mu \mathrm{L}$ of the forward primer and $3 \%$ of formamide) and the thermal conditions (31 cycles for cyclic denaturation at $94^{\circ} \mathrm{C}$ for 


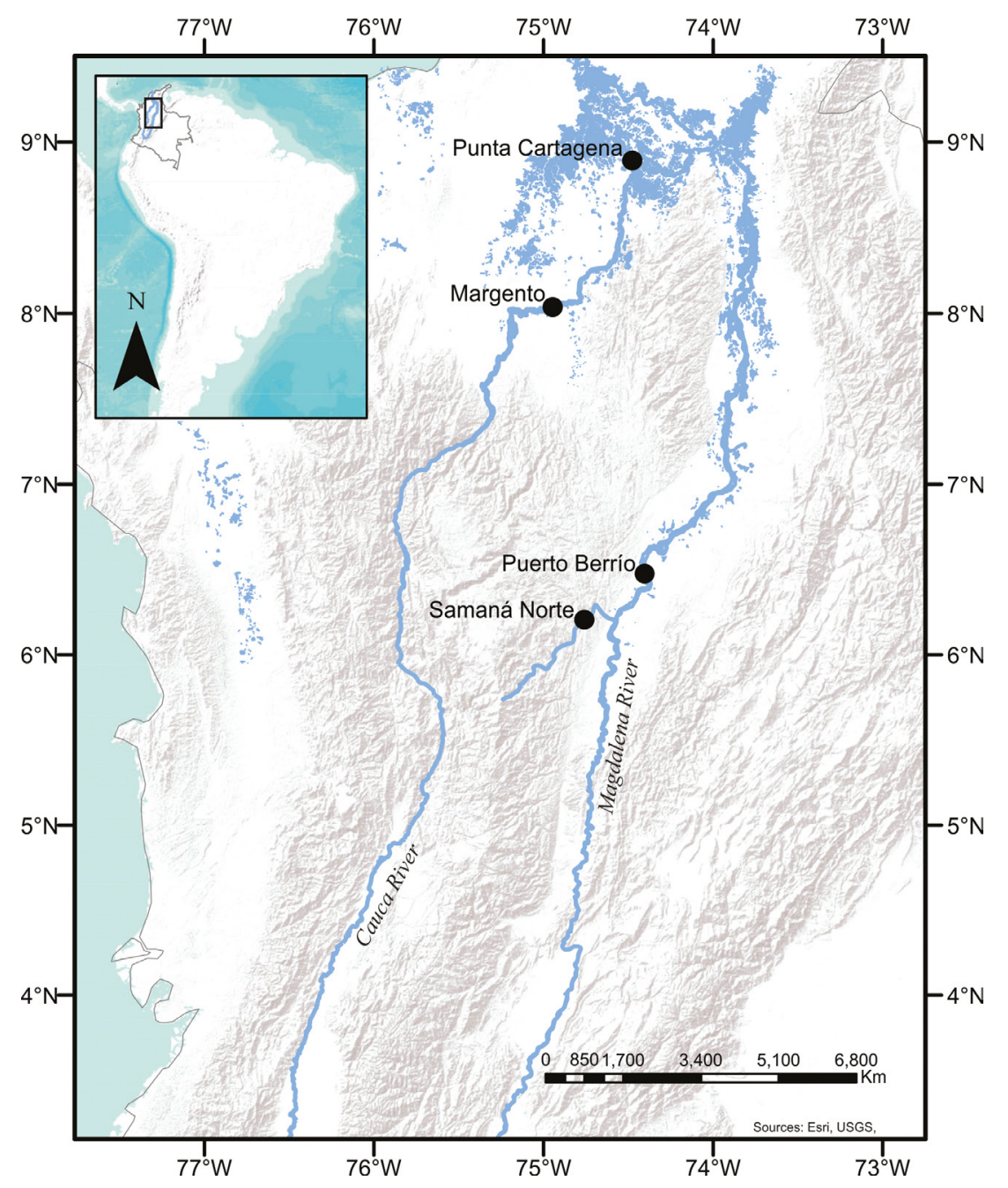

FIGURE 1 I Sampling sites of Pseudoplatystoma magdaleniatum in the Magdalena-Cauca basin.

$30 \mathrm{~s}$ and annealing at $57-59^{\circ} \mathrm{C}$ for $20 \mathrm{~s}$ ). An additional set of pentanucleotide motifs loci were amplified, following the three primers method (Blacket et al., 2012) and using the amplification conditions reported by Landínez-García, Márquez (2018) with some modifications in the final concentrations: $0.5 \mathrm{pmol} / \mu \mathrm{L}$ of tagged forward primer, 1 $\mathrm{pmol} / \mu \mathrm{L}$ of reverse primer and, $0.5 \mathrm{pmol} / \mu \mathrm{L}$ of fluorescently labelled adapter. Thermal profile consisted of $94^{\circ} \mathrm{C}$ for $3 \mathrm{~min}$, followed by 45 cycles of $90^{\circ} \mathrm{C}$ for $20 \mathrm{~s}$ and $56^{\circ} \mathrm{C}$ for 21 s. Finally, a total of 25 microsatellite loci were genotyped as described in LandínezGarcía, Márquez (2016).

Genetic diversity. The average number of alleles per locus $(\mathrm{Na})$ and alleles size range were obtained using GenAlEx v6.51b2 (Peakall, Smouse, 2012, 2006). Detection of amplification errors such as null alleles, stutter bands or dropout effects were assessed using Micro-Checker v2.2.3 (Van Oosterhout et al., 2004). The polymorphic information content (PIC) was calculated using CERVUS v3.0.7 (Marshall et al., 1998). Expected $\left(\mathrm{H}_{\mathrm{E}}\right)$ and observed $\left(\mathrm{H}_{\mathrm{O}}\right)$ heterozygosity, inbreeding coefficients $\left(\mathrm{F}_{\mathrm{IS}}\right)$ 
and departures from Hardy-Weinberg (HWE) and Linkage (LE) equilibria, were calculated using Arlequin v3.5.2.2 (Excoffier, Lischer, 2010). Then, departure from HWE across loci was assessed in the web version of GENEPOP v4.7.5 (Raymond, Rousset, 1995; Rousset, 2008). Additionally, the presence of candidate loci under natural selection was explored using the software BayeScan v2.1 (Foll, Gaggiotti, 2008), setting a prior odd ratio for neutral model of 10:1. Chain parameters included 40 pilot runs of 5,000 iterations each, a sample size of 50,000 and a thinning interval of 10 .

Demographic events. Two tests were performed to evaluate recent and drastic changes in the population size, the modified Garza-Williamson index (M-ratio; Garza, Williamson, 2001), calculated in Arlequin v3.5.2.2 (Excoffier, Lischer, 2010); and the one-tailed Wilcoxon signed-rank test according to three mutational models (Cornuet, Luikart, 1996), calculated in BOTTLENECK v1.2.02 (Piry et al., 1999). Sequential Bonferroni correction was performed in multiple comparisons (Holm, 1979; Rice, 1989). Additionally, the effective population size ( $\mathrm{Ne}$ ) was estimated using the single-sample method based on linkage disequilibrium (LD) (Hills, 1981; Waples, 2006), implemented in the software NeEstimator v2.1 (Do et al., 2014) and considering the lowest allele frequency of 0.05 . The three tests above were conducted in each deme and taking all sites as a single population. Furthermore, to explore migration events, the software GENECLASS2 (Piry et al., 2004) was used to assess probabilities that each individual is a resident in the sampling site or an immigrant from the other locations. The L_home/L_max ratio was used to detect the first-generation migrants, i.e., the ratio between the likelihood of the individual within its putative location and the highest likelihood among all considered locations. The analysis was based on a Bayesian statistical method (Baudouin, Lebrun, 2001), and simulations implemented the unbiased Monte-Carlo resampling method (Paetkau et al., 2004), using 15 loci, 10,000 individuals and 0.01 as type I error threshold.

Genetic structure analysis. GenAlEx v6.51b2 (Peakall, Smouse, 2006, 2012) was used to perform an analysis of molecular variance (AMOVA) and to calculate the standardized statistics F' (Meirmans, 2006) and Jost's $D_{\text {EST }}$ (Jost, 2008). Additionally, a Bayesian clustering analysis was carried out on Structure v2.3.4 (Pritchard et al., 2000), using 500,000 Markov chain Monte Carlo, 50,000 iterations as burn-in and considering LOCPRIOR, admixture and correlated allele frequencies as a priori models. Analysis was conducted setting 20 runs using a range of $\mathrm{K}$ from one to seven. The web-based software StructureSelector ( $\mathrm{Li}, \mathrm{Liu}, 2018$ ) was used to determine the most likely value of $\mathrm{K}$ based on Puechmaille estimators (2016), and the $\operatorname{Ln} \operatorname{Pr}(\mathrm{X} \mid \mathrm{K})$ (Pritchard et al., 2000) and $\Delta \mathrm{K}$ (Evanno et al., 2005) statistics. Furthermore, the membership coefficient matrix (Q-matrix) was plotted using the program Clumpak (Kopelman et al., 2015), integrated in StructureSelector (Li, Liu, 2018). Finally, a discriminant analysis of principal components (DAPC) was obtained using the R package Adegenet (Jombart, 2008), with 30 principal components retained (67.7\% of total variance). 


\section{RESULTS}

Twenty-five microsatellites loci with tetra- (21) and pentanucleotide (4) motifs were developed for P. magdaleniatum (Tab. 1) and no amplification errors were detected by Micro-Checker v2.2.3. Allelic size ranged from 97 to $318 \mathrm{bp}$ and PIC values were above 0.500 (average: 0.756 ). A total of nine loci were excluded from further analysis because showed low levels of polymorphism (Psm29), inconsistent amplification (> 30\% of missing data after genotyping; Psm20, Psm10, Psm17 and, Psm23) or remain to be evaluated in a greater sample due to limited amounts or degraded DNA (Psm42, Psm43, Psm45, Psm50, Psm09). Therefore, a total of 15 loci microsatellite were employed in the final analyses in 147 individuals of P. magdaleniatum from four sampling sites.

TABLE 1 I Characteristics of 25 microsatellite loci developed for Pseudoplatystoma magdaleniatum. F: forward; R: reverse; a-d: tails A-D (Blacket et al., 2012); Rm: repeat motif; Ra: Allelic size range (bp); Na: number of alleles; $\mathrm{H}_{\mathrm{O}}$ : observed heterozygosity; $\mathrm{H}_{\mathrm{E}}$ : expected heterozygosity; P: p-value for Hardy-Weinberg equilibrium test (values in bold denote statistical significance at P < 0.05); PIC: Polymorphic Information Content.

\begin{tabular}{|c|c|c|c|c|c|c|c|c|}
\hline Locus & Primer sequence $\left(5^{\prime}-3^{\prime}\right)$ & $\mathbf{R m}$ & $\mathbf{R a}$ & $\mathbf{N a}$ & $\mathbf{H}_{\mathrm{o}}$ & $\mathbf{H}_{\mathrm{E}}$ & $\mathbf{P}$ & PIC \\
\hline \multirow[t]{2}{*}{ Psm19 } & F:GCTGATTTCTTGGTTTGCTTGG & ATCT & $181-217$ & 10 & 0.782 & 0.826 & 0.072 & 0.863 \\
\hline & R:ATATGGGGCGAGAGGAAAGC & & & & & & & \\
\hline \multirow[t]{2}{*}{ Psm06 } & F:AGCTTACTCATGTGCGTGGG & ATCT & $207-259$ & 14 & 0.827 & 0.881 & 0.118 & 0.855 \\
\hline & R:TCTAAATTTGGCCAGTAGGGG & & & & & & & \\
\hline \multirow[t]{2}{*}{ Psm17 } & F:GAGGCTCTCGAACGAACTGC & AAAC & 259-295 & 10 & 0.832 & 0.867 & 0.672 & 0.846 \\
\hline & R:TCGCGGGAACCAAAGACC & & & & & & & \\
\hline \multirow[t]{2}{*}{ Psm11 } & F:TGATGTGGAAAACTGGAGAGC & ATCT & 132-192 & 14 & 0.822 & 0.868 & 0.433 & 0.844 \\
\hline & R:TGTCGTGTGACTGCGATCC & & & & & & & \\
\hline \multirow[t]{2}{*}{ Psm03 } & F:AAGTGCAAAGTTAAAGACACCACC & AAAG & 144-196 & 12 & 0.777 & 0.854 & 0.052 & 0.843 \\
\hline & R:TCAATATTGTGTATCATTACACCGC & & & & & & & \\
\hline \multirow[t]{2}{*}{ Psm09 } & F:ATGGTTTGAACCAAAAGCGG & TCTG & $246-318$ & 17 & 0.800 & 0.848 & 0.158 & 0.842 \\
\hline & R:TTTGTTTCGGCTTATTCGGG & & & & & & & \\
\hline \multirow[t]{2}{*}{ Psm14 } & F:GACAAGCAGAGTGACACAGGC & ATCT & $106-154$ & 12 & 0.810 & 0.863 & 0.096 & 0.831 \\
\hline & R:AAATGGAGACAGGTGTACAGGG & & & & & & & \\
\hline \multirow[t]{2}{*}{ Psm04 } & F:CGATGTACAGTCTTTTGTGGAGC & ATCT & 111-191 & 20 & 0.847 & 0.872 & 0.055 & 0.828 \\
\hline & R:GCTGTAAGTAAACAATTTCCCTTGG & & & & & & & \\
\hline \multirow[t]{2}{*}{ Psm24 } & F:TGATGTGGGAAGTTGAAGAAGC & ATCT & $199-243$ & 12 & 0.909 & 0.879 & 0.004 & 0.826 \\
\hline & R:GTGAATATGGTGAGTGCCGC & & & & & & & \\
\hline \multirow[t]{2}{*}{ Psm02 } & F:CCATCTTGTGTTGCAATGGG & ATCT & $156-212$ & 15 & 0.860 & 0.827 & 0.392 & 0.825 \\
\hline & R:AGCTTGGTGAATGTTGTGGG & & & & & & & \\
\hline \multirow[t]{2}{*}{ Psm10 } & F:AATTAGTGTGTTGCTTGCCAGG & TCTG & 140-196 & 13 & 0.708 & 0.823 & 0.016 & 0.825 \\
\hline & R:GTGCCAAGGCTTTGTCTTCC & & & & & & & \\
\hline \multirow[t]{2}{*}{ Psm20 } & F:TTCTCTGATGCCTCTGCTCG & AACT & $236-276$ & 11 & 0.846 & 0.870 & 0.566 & 0.823 \\
\hline & R:TTTTAAGCCTGCACACACTTTAGC & & & & & & & \\
\hline \multirow[t]{2}{*}{ Psm01 } & F:СССАСТСАССТАССGAAACC & ATCT & 97-145 & 12 & 0.901 & 0.875 & 0.251 & 0.890 \\
\hline & R:TAGATGGACAGGTGAACGGG & & & & & & & \\
\hline \multirow[t]{2}{*}{ Psm18 } & F:TGGCTTAGCGAATCACATGC & AAAG & $199-235$ & 10 & 0.851 & 0.817 & 0.619 & 0.840 \\
\hline & R:GTGTTGTGTTTCATTGGGGC & & & & & & & \\
\hline
\end{tabular}




\begin{tabular}{|c|c|c|c|c|c|c|c|c|}
\hline Locus & Primer sequence $\left(5^{\prime}-3^{\prime}\right)$ & $\mathbf{R m}$ & $\mathbf{R a}$ & $\mathrm{Na}$ & $\mathbf{H}_{0}$ & $\mathbf{H}_{\mathrm{E}}$ & $\mathbf{P}$ & PIC \\
\hline \multirow[t]{2}{*}{ Psm22 } & F:TGAAACTGATAGGGCAACAGC & ATGG & $165-209$ & 12 & 0.782 & 0.845 & 0.037 & 0.795 \\
\hline & R:TGTGTCTGGAATAGAATCTGGACC & & & & & & & \\
\hline \multirow[t]{2}{*}{ Psm21 } & F:TCAGCTCCACTGATCTACTGACG & ATCT & $217-269$ & 12 & 0.729 & 0.675 & 0.972 & 0.769 \\
\hline & R:GGCAGGTGTGTTGATTGGG & & & & & & & \\
\hline \multirow[t]{2}{*}{ Psm23 } & F:CTGGGGCTATATGGTCTGGC & AAAG & 273-309 & 12 & 0.826 & 0.813 & 0.228 & 0.745 \\
\hline & R:TCTTTGCTGATTTACTTCTTTGGC & & & & & & & \\
\hline \multirow[t]{2}{*}{ Psm25 } & F:TCTGGTCACGAACATCCTGC & ATGG & $120-144$ & 8 & 0.689 & 0.691 & 0.863 & 0.740 \\
\hline & R:TGCAGTGAGGAGAAGGATTGG & & & & & & & \\
\hline \multirow[t]{2}{*}{$\operatorname{Psm} 42^{\mathrm{b}}$} & F:CAAAATACTGCAAACAAAACTGAGC & AAAAC & $216-275$ & 11 & 0.727 & 0.732 & 0.682 & 0.730 \\
\hline & R:CTTATATCGCACAGCGCAGG & & & & & & & \\
\hline \multirow[t]{2}{*}{ Psm16 } & F:TGTAGCCTCACCTCTGCTGC & AAAG & $166-190$ & 7 & 0.563 & 0.586 & 0.127 & 0.652 \\
\hline & R:TGTCCCAGTTCCCTGTGAGG & & & & & & & \\
\hline \multirow[t]{2}{*}{ Psm50 ${ }^{\mathrm{a}}$} & F:GCGGTCTCTCTTCATAGGGG & AAGAG & $272-307$ & 9 & 0.664 & 0.678 & 0.108 & 0.638 \\
\hline & R:ACGGAGGCCATTATGAGTCG & & & & & & & \\
\hline \multirow[t]{2}{*}{$\operatorname{Psm} 45^{\mathrm{C}}$} & F:GTGCTGTTCTGCATTTTCCG & AATAG & $287-312$ & 6 & 0.694 & 0.667 & 0.955 & 0.680 \\
\hline & R:CAGATGGTGACAGAGGCAGG & & & & & & & \\
\hline \multirow[t]{2}{*}{$\operatorname{Psm} 43^{d}$} & F:AACCTTTGGCAGGGTTTAAGG & AAAAG & $128-158$ & 7 & 0.281 & 0.608 & 0.000 & 0.563 \\
\hline & R:CACCCACATTGAGAACTGGC & & & & & & & \\
\hline \multirow[t]{2}{*}{ Psm26 } & F:AGCTTGCTAGCAGTTGTGCC & ATCT & 169-201 & 8 & 0.594 & 0.554 & 0.747 & 0.554 \\
\hline & R:TCACGTCTGTTGTTCATTCCC & & & & & & & \\
\hline \multirow[t]{2}{*}{ Psm29 } & F:CCGATGACGTAACAATTTACCC & ATCT & 190-194 & 2 & 0.551 & 0.493 & 0.150 & 0.473 \\
\hline & R:CACGTCTAGAGACACCAAATACTGG & & & & & & & \\
\hline
\end{tabular}

Genetic diversity. The numbers of alleles per locus were similar in all sites (Na: 9-10) and values of $\mathrm{H}_{\mathrm{O}}$ and $\mathrm{H}_{\mathrm{E}}$ ranged from 0.762 to 0.798 , and 0.770 to 0.791 , respectively (Tab. 2). The inbreeding coefficient values $\left(\mathrm{F}_{\mathrm{IS}}\right)$ were non-significant and no departure of HWE was detected in the samples studied (Tab. 2). Additionally, no departure of LE and no evidence of natural selection in any locus were found (posterior probability: 0.061-0.193, i.e., Bayes Factor favoring neutral model).

Demographic events. Both modified Garza-Williamson index (M-ratio: 0.200.22 ) and significant results of the Wilcoxon signed-rank test for IAM model in each location and pooled samples (Tab. 3) indicate a recent reduction in the population size, contrasting the results from SMM and TPM. Since few loci follow the strict SMM, IAM or TPM are considered the most likely mutational models in microsatellites (Piry et al., 1999). Additionally, the effective population size showed low values in Margento and Punta Cartagena contrasting to that observed in the Magdalena River and in the overall estimation (Tab. 3). On the other hand, four of 147 individuals were detected as potential immigrants in their sampling sites and were assigned to the most likely location of origin. Specifically, one individual from Margento $(\mathrm{P}=0.005)$ and one from Punta Cartagena $(\mathrm{P}=0.001)$ were assigned to Samaná Norte, whereas one individual from Puerto Berrío was assigned to Punta Cartagena $(P=0.004)$, and one from Samaná Norte was assigned to Margento $(\mathrm{P}=0.008)$. 
TABLE 2 I Genetic diversity of Pseudoplatystoma magdaleniatum from four sampling sites in the Magdalena-Cauca basin (Colombia) using 15 microsatellite loci. N: sample size; Na: average number of alleles per locus; $\mathrm{H}_{\mathrm{O}}$ : observed heterozygosity; $\mathrm{H}_{\mathrm{E}}$ : expected heterozygosity; $\mathrm{F}_{\mathrm{IS}}$ : inbreeding coefficient; P: p-value for Hardy-Weinberg equilibrium test.

\begin{tabular}{r|c|c|c|c|c|c|c|}
\hline \multicolumn{1}{|c|}{ Site } & $\mathbf{N}$ & $\mathbf{N a}$ & $\mathbf{H o}$ & $\mathbf{H}_{\mathrm{E}}$ & $\mathbf{F}_{\text {IS }}$ & $\mathbf{P}$ \\
\hline Margento & 30 & 8.933 & 0.798 & 0.777 & -0.014 & 0.880 \\
\hline Punta Cartagena & 32 & 9.133 & 0.762 & 0.770 & 0.011 & 0.262 \\
Puerto Berrío & 57 & 10.000 & 0.773 & 0.791 & 0.010 & 0.103 \\
\hline Samaná Norte & 28 & 9.000 & 0.798 & 0.778 & -0.048 & 0.080 \\
\hline
\end{tabular}

TABLE 3 I Bottleneck test and effective population size (Ne) estimation in four sampling sites of the Magdalena-Cauca basin. P-values from one tailed Wilcoxon signed-rank test under infinite alleles model (IAM), stepwise mutation model (SMM) and two-phase mutation model (TPM). M-ratio: modified index of Garza-Williamson. Values in bold denote statistical significance after correction for multiple comparisons.

\begin{tabular}{r|c|c|c|c|c|}
\hline Site & IAM & SMM & TPM & M-ratio & Ne \\
\hline Margento & $\mathbf{0 . 0 0 8}$ & 0.489 & 0.524 & 0.20 & 171.4 \\
Punta Cartagena & $\mathbf{0 . 0 1 2}$ & 0.064 & 0.359 & 0.21 & 187.9 \\
Puerto Berrío & $\mathbf{0 . 0 0 0}$ & 0.252 & 0.083 & 0.22 & Infinite \\
Samaná Norte & $\mathbf{0 . 0 0 0}$ & 0.330 & 0.188 & 0.20 & 6317.9 \\
Overall & $\mathbf{0 . 0 0 0}$ & 0.995 & 0.104 & 0.21 & 1748.7 \\
\hline
\end{tabular}

A

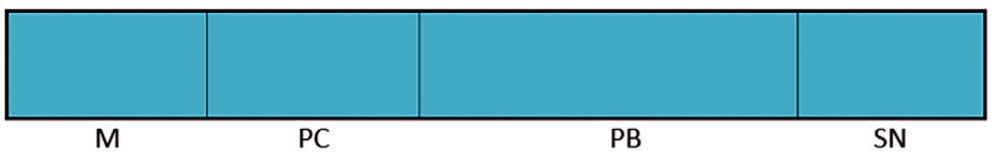

B

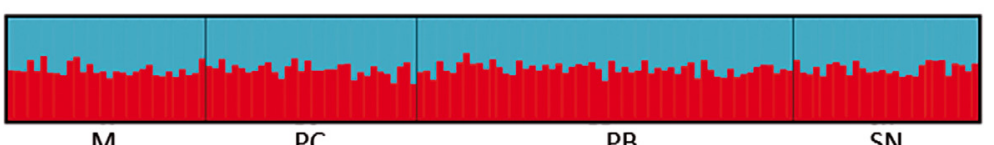

C

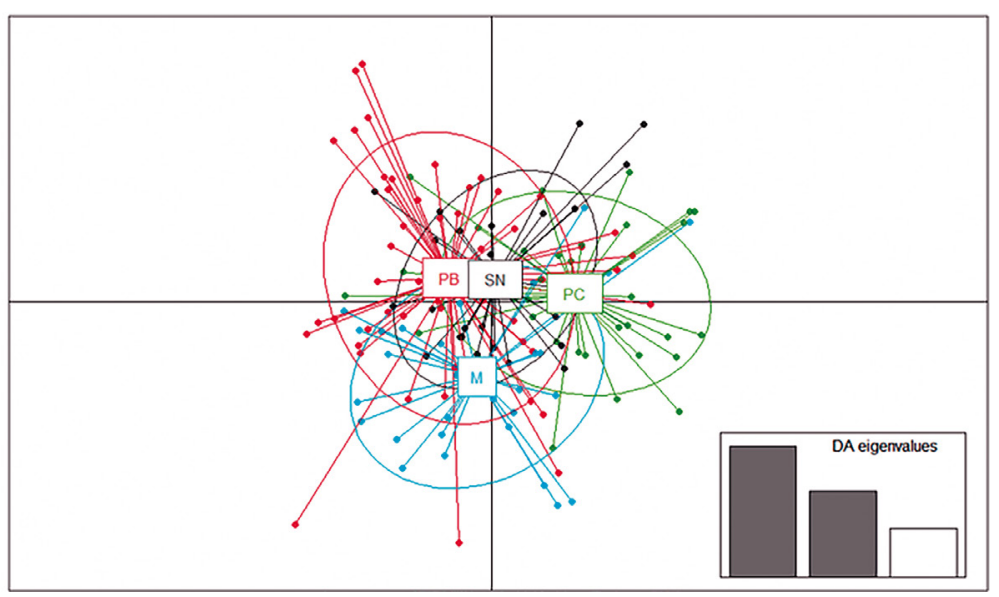

FIGURE 2 I Results of Structure (A, B) and Discriminant analysis of principal components (C) for Pseudoplatystoma magdaleniatum. A: K = 1; B: K = 2; M: Margento, PC: Punta Cartagena, PB: Puerto Berrío, SN: Samaná Norte. 
TABLE 4 I Pairwise comparisons of genetic structure estimators. Non-significant values above and below diagonal show Jost's $\mathrm{D}_{\mathrm{EST}}$ and $\mathrm{F}_{\mathrm{ST}}^{\prime}$ statistics, respectively.

\begin{tabular}{|c|c|c|c|c|}
\hline Site & Margento & Punta Cartagena & Puerto Berrío & Samaná Norte \\
\hline Margento & - & 0.005 & 0.005 & -0.011 \\
\hline Punta Cartagena & 0.022 & - & 0.006 & -0.017 \\
\hline Puerto Berrío & 0.016 & 0.003 & - & -0.016 \\
\hline Samaná Norte & -0.002 & -0.008 & -0.016 & - \\
\hline
\end{tabular}

Population structure. Although $\Delta \mathrm{K}$ suggested that $\mathrm{K}=2$, every individual had similar membership probability to each cluster, which is concordant with both the maximum $\log$ likelihood and the MedMeaK and MedMedK statistics for $\mathrm{K}=1$ (Figs. 2A-B). Likewise, the results from DAPC (Fig. 2C), AMOVA $\left(\mathrm{F}_{\text {ST }}^{\prime}(3,293)=0.003, \mathrm{P}=0.352\right)$, $\mathrm{F}_{\mathrm{ST}}$ and $\mathrm{D}_{\mathrm{EST}}$ statistics showed genetic similarities among sites (Tab. 4). Additionally, AMOVA showed that $92 \%$ of genetic differences was explained by variance within individuals.

\section{DISCUSSION}

This study tested three hypotheses related to the population genetics of P. magdaleniatum. The a priori expectations were that this species exhibits: (1) low levels of genetic diversity, (2) evidence of recent reductions of population size, likely resulting from overfishing and other anthropic threats, and (3) gene flow given its middle migratory range and the absence of physical barriers among sampling locations. To test these hypotheses, this study developed 25 microsatellite loci containing tetra- and pentanucleotide motifs to avoid genotyping errors that may rise during allelic assignment (Dewoody et al., 2006). Selected loci for population genetics analysis showed high polymorphism (mean total Na: 12) with PIC values ranging from 0.554-0.863, which indicates that these markers are informative (Botstein et al., 1980) and suitable for further population genetic studies in P. magdaleniatum.

Results obtained in this study did not support the hypothesis of low genetic diversity in samples of P. magdaleniatum as we found high number of alleles per locus, and high values of observed and expected heterozygosities. Given the difference in the motif sizes of the loci used, average values of alleles per locus may not be strictly comparable with those found in congeners. However, mean values of expected heterozygosity were similar to the highest value for P. corruscans $\left(\mathrm{H}_{\mathrm{E}}: 0.3213-0.9424\right)$ (Revaldaves et al., 2005; Pereira et al., 2009; Prado et al., 2018) and P. reticulatum $\left(\mathrm{H}_{\mathrm{E}}: 0.056-0.885\right)$ from Paraguay River and Upper Paraná basin (Abreu et al., 2009; Prado et al., 2014) and for P. punctifer $\left(\mathrm{H}_{\mathrm{E}}: 0.553-0.839\right)$ from Madeira and Purús rivers (Telles et al., 2014). Finally, values of expected heterozygosity were higher than the average value reported for Neotropical Siluriformes $\left(\mathrm{H}_{\mathrm{E}}\right.$ : $\left.0.609 \pm 0.210\right)$ using microsatellite loci (see Hilsdorf, Hallerman, 2017).

This work shows evidence of a recent genetic bottleneck in P. magdaleniatum, supporting the hypothesis of a reduced population size, consistent with reports of landings decline of this species in the Magdalena basin (Mojica et al., 2012). Despite 
the high genetic diversity found in P. magdaleniatum, the low values of M-ratio may indicate that number of alleles of this species were higher in the past (Garza, Williamson, 2001) and, therefore, suggest a recent loss of allelic diversity as consequence of a drastic reduction in the population size. Additionally, the expected heterosigosity $\left(\mathrm{H}_{\mathrm{E}}\right)$ exceeded the simulated heterozygosity using the current number of alleles under mutation-drift equilibrium $\left(\mathrm{H}_{\mathrm{eq}}\right)$, as was evidenced under the Infinite Allele Model (Cornuet, Luikart, 1996). Other studies in large Neotropical Siluriformes as P. corruscans, P. reticulatum and Conorhynchos conirostris (Valenciennes, 1840) also found evidence of bottleneck and high genetic diversity using microsatellites in populations that inhabit drastically affected areas by human activities as river damming and pollution (Carvalho, Beheregaray, 2018; Prado et al., 2018).

Following Frankham et al. (2014), the effective population sizes of P. magdaleniatum $(<500)$ in the Cauca river sites (Margento and Punta Cartagena) indicate that this species exhibits limitations in its long-term evolutionary potential. This outcome is in line with drastic reduction in the population size of P. magdaleniatum found in this study. Despite the bottlenecked populations, the estimated high effective population sizes (infinite, 6317.9) show that P. magdaleniatum does not exhibit limitations in its long-term evolutionary potential in the Magdalena River (Puerto Berrío and Samaná Norte). However, these discrepancies may be a consequence of the estimation method bias although the factors that influence it remain unclear (Waples, England, 2011; Waples et al., 2014; Wang et al., 2016). Thus, we suggest using these values exclusively as a reference for further studies using a greater number of samples and markers, which might improve the confidence of this method (Hill, 1981; Pudovkin et al., 1996; Waples, Do, 2010).

This study supports the hypothesis of gene flow in P. magdaleniatum in the MagdalenaCauca basin, consistent with the migration range of this species and the absence of physical barriers among sampling sites. Although P. magdaleniatum is cataloged as a medium distance migratory species (100-500 km Zapata, Usma, 2013), the most distant sampling sites of this study are separated by at least $680 \mathrm{~km}$, which might suggest that longitudinal migration of P. magdaleniatum could be longer than the currently reported for this species. This idea agrees with the analysis of detection of potential migrants between Margento and Samaná Norte, although this hypothesis must be further tested by mark-recapture studies (Lucas, Baras, 2000). In addition, the high fertility (Arce Hernández, 2008; Jiménez-Segura et al., 2009) coupled with dynamic hydrological interactions among rivers, tributaries and floodplains (Jiménez-Segura et al., 2010) may facilitate larval dispersal and eventually connect distant populations within the Magdalena-Cauca basin. Furthermore, as previously reported in Characiformes (Landínez-García, Márquez, 2018), the observed gene flow in P. magdaleniatum may also be a consequence of extreme floods resulting from La Niña event between 20102011 (IDEAM - Instituto de Hidrología Meteorología y Estudios Ambientales, 2014) in the Magdalena-Cauca basin. Further investigations in a broader geographic scale are required to have a wider perspective on the genetic structure of this emblematic species.

In conclusion, P. magdaleniatum behaves as a single panmictic population with a high genetic diversity that has experienced recent reduction in its population size. This provides a baseline for future studies aiming to monitor the genetic variability of this species throughout the Magdalena-Cauca basin. Additionally, in the face of the current anthropic threats, both demographic projection analyses and genetic information 
must be incorporated in conservation and management policies that ensure long-term preservation of this important fishery resource.

\section{ACKNOWLEDGMENTS}

This work was funded by Universidad Nacional de Colombia Sede Medellín and Empresas Públicas de Medellín, Grant CT-2013-002443-R1 "Variación genotípica y fenotípica de poblaciones de especies reófilas presentes en el área de influencia del proyecto hidroeléctrico Ituango"; Grant CT-2019-000661 "Variabilidad genética de un banco de peces de los sectores medio y bajo del Río Cauca". The authors thank the Centro Nacional de Secuenciación Genómica, Universidad de Antioquia (Medellín, Colombia) for assistance in bioinformatics analysis.

\section{REFERENCES}

- Abreu MM, Pereira LHG, Vila VB, Foresti F, Oliveira C. Genetic variability of two populations of Pseudoplatystoma reticulatum from the Upper Paraguay River Basin. Genet Mol Biol. 2009; 32(4):868-73. https://doi.org/10.1590/S141547572009005000075

- Álvarez-León R. Las vedas como regulación del aprovechamiento sostenible de los recursos hidrobiológicos de las aguas dulces, estuarinas y marinas en Colombia. Summa Iuris. 2016; 4(2):287326. https://doi.org/10.21501/23394536.2330

- Angarita H, Wickel AJ, Sieber J, Chavarro J, Maldonado-Ocampo JA, Herrera-R GA et al. Basin-scale impacts of hydropower development on the Mompós Depression wetlands, Colombia. Hydrol Earth Syst Sci. 2018; 22(5):2839-65. https:// doi.org/10.5194/hess-22-2839-2018

- Arce Hernández M. Evaluación del estado de poblaciones de bagre rayado Pseudoplatystoma magdaleniatum en la cuenca media del río Magdalena durante la temporada de subienda del 2004. Rev Acad Colomb Cienc Exactas Fis Nat. 2008; 32(123):257-66. Available from: https:// raccefyn.co/index.php/raccefyn/issue/ view/173

- Barletta M, Jaureguizar AJ, Baigun C, Fontoura NF, Agostinho AA, Almeida-Val VMF et al. Fish and aquatic habitat conservation in South America: a continental overview with emphasis on neotropical systems. J Fish Biol. 2010; 76(9):2118-76. https://doi. org/10.1002/9781118394380.ch27
- Baudouin L, Lebrun P. An operational Bayesian approach for the identification of sexually reproduced cross-fertilized populations using molecular markers. Acta Hortic. 2001; 546(1):81-93. https://doi. org/10.17660/actahortic.2001.546.5

- Blacket MJ, Robin C, Good RT, Lee SF, Miller AD. Universal primers for fluorescent labelling of PCR fragmentsan efficient and cost-effective approach to genotyping by fluorescence. Mol Ecol Resour. 2012; 12(3):456-63. https://doi. org/10.1111/j.1755-0998.2011.03104.x

- Botstein D, White RL, Skolnick M, Davis RW. Construction of a genetic linkage map in man using restriction fragment length polymorphisms. Am J Hum Genet. 1980; 32(3):314-31. Available from: https:// www.ncbi.nlm.nih.gov/pmc/articles/ PMC1686077/

- Buitrago-Suárez UA. Anatomía comparada y evolución de las especies de Pseudoplatystoma Bleeker 1862 (Siluriformes: Pimelodidae). Rev Acad Colomb Cienc Exactas Fis Nat. 2006; 30(114):117-41. Available from: https:// raccefyn.co/index.php/raccefyn/issue/ view/162/147

- Buitrago-Suárez UA, Burr BM. Taxonomy of the catfish genus Pseudoplatystoma Bleeker (Siluriformes: Pimelodidae) with recognition of eight species. Zootaxa. 2007; 1512:1-38. https://doi.org/10.11646/ zootaxa.1512.1.1 
- Carranza-Lopez L, Caballero-Gallardo K, Cervantes-Ceballos L, Turizo-Tapia A, Olivero-Verbel J. Multicompartment mercury contamination in major gold mining districts at the Department of Bolivar, Colombia. Arch Environ Con Tox. 2019; 76(4):640-49. https://doi.org/10.1007/ s00244-019-00609-w

- Carvalho DC, Beheregaray LB. Conservation genetics of the threatened catfish Conorhynchos conirostris (Siluriformes: incertae sedis), an evolutionary relict endemic to the São Francisco River Basin, Brazil. Conserv Genet. 2018; 19(5):1223-30. https://doi. org/10.1007/s10592-018-1090-7

- Cornuet JM, Luikart G. Description and power analysis of two tests for detecting recent population bottlenecks from allele frequency data. Genetics. 1996; 144(1):2001-14. Available from: https:// www.genetics.org/content/144/4/2001

- Dewoody J, Nason JD, Hipkins VD. Mitigating scoring errors in microsatellite data from wild populations. Mol Ecol Notes. 2006; 6(4):951-57. https://doi. org/10.1111/j.1471-8286.2006.01449.x

- Do C, Waples RS, Peel D, Macbeth GM, Tillett BJ, Ovenden JR. NeEstimator v2: Re-implementation of software for the estimation of contemporary effective population size $(\mathrm{Ne})$ from genetic data. Mol Ecol Resour. 2014; 14(1):209-14. https://doi. org/10.1111/1755-0998.12157

- Evanno G, Regnaut S, Goudet J. Detecting the number of clusters of individuals using the software STRUCTURE: A simulation study. Mol Ecol. 2005; 14(8):2611-20. https://doi.org/10.1111/j.1365294X.2005.02553.x

- Excoffier L, Lischer HEL. Arlequin suite ver 3.5: A new series of programs to perform population genetics analyses under Linux and Windows. Mol Ecol Resour. 2010; 10(3):564-47. https://doi. org/10.1111/j.1755-0998.2010.02847.x

- Fernandez-Silva I, Whitney J, Wainwright B, Andrews KR, YlitaloWard H, Bowen BW et al. Microsatellites for next-generation ecologists: a postsequencing bioinformatics pipeline. PLoS One. 2013; 8(2):e55990. https://doi. org/10.1371/journal.pone.0055990
- Foll M, Gaggiotti O. A genomescan method to identify selected loci appropriate for both dominant and codominant markers: A Bayesian perspective. Genetics. 2008; 180(2):977-93. https://doi.org/10.1534/genetics.108.092221

- Frankham R, Bradshaw CJA, Brook BW. Genetics in conservation management: Revised recommendations for the 50/500 rules, Red List criteria and population viability analyses. Biol Conserv. 2014; 170:56-63. https://doi.org/10.1016/j. biocon.2013.12.036

- Fricke R, Eschmeyer W, Fong JD. Eschmeyer's Catalog of Fishes [Internet]. San Francisco: California Academy of Science; 2020. Available from: http:// researcharchive.calacademy.org/research/ ichthyology/catalog/SpeciesByFamily.asp

- Garza JC, Williamson EG. Detection of reduction in population size using data from microsatellite loci. Mol Ecol. 2001; 10(2):305-18. https://doi.org/10.1046/j.1365294x.2001.01190.x

- Guichoux E, Lagache L, Wagner S, Chaumeil P, Léger P, Lepais 0 et al. Current trends in microsatellite genotyping. Mol Ecol Resour. 2011; 11(4):591-611. https://doi.org/10.1111/ j.1755-0998.2011.03014.x

- Hill WG. Estimation of effective population size from data on linkage disequilibrium. Genet. Res. 1981; 38(3):209-16. https://doi. org/10.1017/S0016672300020553

- Hilsdorf AWS, Hallerman EM. Characterization of genetic resources. In: Hilsdorf AWS, Hallerman EM, editors. Resources of Neotropical Fishes. Switzerland: Springer International Publishing; 2017. p.82-95. https://doi. org/10.1007/978-3-319-55838-7

- Holm S. A simple sequentially rejective multiple test procedure. Scand J Stat. 1979; 6(2):65-70. Available from: http://www. jstor.org/stable/4615733

- IDEAM - Instituto de Hidrología Meteorología y Estudios Ambientales. Boletín de seguimiento fenómeno El Niño y La Niña [Internet]. Bogotá D.C.: IDEAM; 2014. Available from: http://www.ideam. gov.co/web/tiempo-y-clima/boletin-deseguimiento-fenomeno-el-nino-y-la-nina 
- Jiménez-Segura LF, Palacio J, Leite R. River flooding and reproduction of migratory fish species in the Magdalena River basin, Colombia. Ecol Freshw Fish. 2010; 19(2):178-86. https://doi.org/10.1111/ j.1600-0633.2009.00402.x

- Jiménez-Segura LF, Palacio J, López R. Características biológicas del blanquillo Sorubim cuspicaudus Littmann; Burr y Nass, 2000 y bagre rayado Pseudoplatystoma magnaleniatum Buitrago-Suárez y Burr, 2007 (Siluriformes: Pimelodidae) relacionadas con su reproducción en la Cuenca Media del río Magdalena, Colombia. Actual Biol. 2009; 31(90):53-66.

- Jombart T. adegenet: A R package for the multivariate analysis of genetic markers. Bioinformatics. 2008; 24(11):1403-1405. https://doi.org/10.1093/bioinformatics/ btn129

- Jost L. $\mathrm{G}_{\mathrm{ST}}$ and its relatives do not measure differentiation. Mol Ecol. 2008; 17(18):4015-26. https://doi.org/10.1111/ j.1365-294X.2008.03887.x

- Kopelman NM, Mayzel J, Jakobsson M, Rosenberg NA, Mayrose I. Clumpak: A program for identifying clustering modes and packaging population structure inferences across K. Mol Ecol Resour. 2015; 15(5):1179-91. https://doi.org/10.1111/17550998.12387

- Landínez-García RM, Marquez EJ. Microsatellite loci development and population genetics in Neotropical fish Curimata mivartii (Characiformes: Curimatidae). PeerJ. 2018; 6(2):e5959. https://doi.org/10.7717/peerj.5959

- Landínez-García RM, Márquez EJ. Development and characterization of 24 polymorphic microsatellite loci for the freshwater fish Ichthyoelephas longirostris (Characiformes: Prochilodontidae). PeerJ. 2016; 4(9):e2419. https://doi.org/10.7717/ peerj.2419

- Lasso CA, Agudelo Córdoba E, JiménezSegura LF, Ramírez-Gil H, MoralesBetancourt M, Ajiaco-Martínez RE, Paula Gutiérrez F, Usma Oviedo JS, Muñoz Torres SE. Sanabria Ochoa AI. I. Catálogo de los recursos pesqueros continentales de Colombia. Bogotá, D.C.: Serie Editorial Recursos Hidrobiológicos y Pesqueros Continentales de Colombia. Instituto de Investigación de Recursos Biológicos Alexander von Humboldt (IAvH); 2011.
- Li YL, Liu JX. StructureSelector: A webbased software to select and visualize the optimal number of clusters using multiple methods. Mol Ecol Resour. 2018; 18(1):17677. https://doi.org/10.1111/1755-0998.12719

- Lucas MC, Baras E. Methods for studying spatial behaviour of freshwater fishes in the natural environment. Fish Fish. 2000; 1(4):283-316. https://doi.org/10.1046/j.14672979.2000.00028.x

- Malabarba LR, Malabarba MC. Chapter 1 - Phylogeny and classification of Neotropical fish. In: Baldisserotto B, Criscuolo E, Cyrino JE., editors. Biology and Physiology of Freshwater Neotropical Fish. San Diego: Academic Press; 2020. p.1-19.

- Marshall TC, Slate J, Kruuk LEB, Pemberton JM. Statistical confidence for likelihood-based paternity inference in natural populations. Mol Ecol. 1998; 7(5):639-55. https://doi.org/10.1046/j.1365294x.1998.00374.x

- Meirmans PG. Using the AMOVA framework to estimate a standardized genetic differentiation measure. Evolution (NY). 2006; 60(11):2399-402. https://doi. org/10.1111/j.0014-3820.2006.tb01874.x

- Mojica JI, Usma JS, Álvarez-León R, Lasso CA. Libro rojo de peces dulceacuícolas de Colombia 2012. Bogotá D.C.: Instituto de Investigación de Recursos Biológicos Alexander von Humboldt, Instituto de Ciencias Naturales de la Universidad Nacional de Colombia, WWF Colombia, Universidad de Manizales; 2012.

- Mojica JI, Valderrama M, JiménezSegura L, Alonso JC. Pseudoplatystoma magdaleniatum. The IUCN Red List of Threatened Species 2016: e.T58439165A61474168 [Internet]. Available from: https://dx.doi. org/10.2305/IUCN.UK.2016-1.RLTS. T58439165A61474168.en

- Paetkau D, Slade R, Burden M, Estoup A. Genetic assignment methods for the direct, real-time estimation of migration rate: A simulation-based exploration of accuracy and power. Mol Ecol. 2004; 13(1):55-65. https://doi.org/10.1046/j.1365294X.2004.02008.x

- Peakall R, Smouse PE. GenAlEx 6.5: genetic analysis in Excel. Population genetic software for teaching and research-an update. Bioinformatics. 2012; 28(9):2537-39. https://doi.org/10.1093/ bioinformatics/bts460 
- Peakall R, Smouse PE. GENALEX 6: genetic analysis in Excel. Population genetic software for teaching and research. Mol Ecol Notes. 2006; 6(1):288-95. https:// doi.org/10.1111/j.1471-8286.2005.01155.x

- Pereira LHG, Foresti F, Oliveira C. Genetic structure of the migratory catfish Pseudoplatystoma corruscans (Siluriformes: Pimelodidae) suggests homing behaviour. Ecol Freshw Fish. 2009; 18(2):215-25. https://doi.org/10.1111/j.16000633.2008.00338.x

- Piry S, Alapetite A, Cornuet J-M, Paetkau D, Baudouin L, Estoup A. GENECLASS2: A software for genetic assignment and first-generation migrant detection. J Hered. 2004; 95(6):536-39. https://doi.org/10.1093/ jhered/esh074

- Piry S, Luikart G, Cornuet JM. BOTTLENECK: A computer program for detecting recent reductions in the effective population size using allele frequency data. J Hered. 1999; 90(4):502-503. https:// doi.org/10.1093/jhered/90.4.502

- Prado FD, Fernandez-Cebrián R, Foresti F, Oliveira C, Martínez P, Porto-Foresti F. Genetic structure and evidence of anthropogenic effects on wild populations of two neotropical catfishes: baselines for conservation. J Fish Biol. 2018; 92(1):55-72. https://doi.org/10.1111/jfb.13486

- Prado FD, Pardo BG, Guerra-Varela J, Senhorini JA, Martínez P, Foresti F et al. Development and characterization of 16 microsatellites for the Neotropical catfish Pseudoplatystoma reticulatum and cross species analysis. Conserv Genet Resour. 2014; 6(3):679-81. https://doi.org/10.1007/ s12686-014-0180-1

- Pritchard JK, Stephens M, Donnelly P. Inference of population structure using multilocus genotype data. Genetics. 2000; 155(2):945-59. Available from: https:// www.genetics.org/content/155/2/945

- Pudovkin AI, Zaykin DV, Hedgecock D. On the potential for estimating the effective number of breeders from heterozygote-excess in progeny. Genetics. 1996; 144(1):383-87.

- Puechmaille SJ. The program STRUCTURE does not reliably recover the correct population structure when sampling is uneven: subsampling and new estimators alleviate the problem. Mol Ecol Resour. 2016; 16(3):608-27. https://doi. org/10.1111/1755-0998.12512
- Rangel-Medrano JD, Alzate JF, Márquez EJ. Complete mitochondrial genome of the Neotropical catfish Pseudoplatystoma magdaleniatum (Siluriformes, Pimelodidae). Mitochondrial DNA, Part A. 2016; 27(6):4033-34. https://doi.org/10.3109 /19401736.2014.1003830

- Raymond M, Rousset F. GENEPOP (Version 1.2): Population Genetics Software for Exact Tests and Ecumenicism. J Hered. 1995; 86(3):248-49. https://doi.org/10.1093/ oxfordjournals.jhered.a111573

- Reis RE, Albert JS, Di Dario F, Mincarone MM, Petry P, Rocha LA. Fish biodiversity and conservation in South America. J Fish Biol. 2016; 89(1):12-47. https://doi. org/10.1111/jfb.13016

- Revaldaves E, Pereira LHG, Foresti F, Oliveira C. Isolation and characterization of microsatellite loci in Pseudoplatystoma corruscans (Siluriformes: Pimelodidae) and cross-species amplification. Mol Ecol Notes. 2005; 5(3):463-65. https://doi.org/10.1111/ j.1471-8286.2005.00883.x

- Rice WR. Analyzing tables of statistical tests. Evolution (NY). 1989; 43(1):223-25. https://doi.org/10.2307/2409177

- Rousset F. GENEPOP'007: A complete reimplementation of the GENEPOP software for Windows and Linux. Mol Ecol Resour. 2008; 8(1):103-06. https://doi.org/10.1111/ j.1471-8286.2007.01931.x

- Saulo-Machado AC, Formiga KM, Ortiz MF, Sousa ACB, Alves-Gomes JA, Batista JS. Polymorphic microsatellite DNA markers for the Amazonian catfish Pseudoplatystoma punctifer (Siluriformes: Pimelodidae). Conserv Genet Resour. 2011; 3(2):307-10. https://doi.org/10.1007/s12686010-9349-4

- Telles MPC, Collevatti RG, Braga RS, Guedes LBS, Castro TG, Costa MC et al. Geographical genetics of Pseudoplatystoma punctifer (Castelnau, 1855) (Siluriformes, Pimelodidae) in the Amazon Basin. Genet Mol Res. 2014; 13(2):3656-66. https://doi. org/10.4238/2014.May.9.8

- Vaini JO, Amaral Crispim B, Santos Silva D, Benites C, Russo M, Grisolia A. Genetic variability of pure Pseudoplatystoma corruscans and Pseudoplatystoma reticulatum individuals in the Paraná and Paraguay River basins. Fisheries Sci. 2016; 82(4):605-11. https://doi.org/10.1007/ s12562-016-0999-3 
- Van Oosterhout C, Hutchinson WF, Wills DPM, Shipley P. MICRO-CHECKER: Software for identifying and correcting genotyping errors in microsatellite data. Mol Ecol Notes. 2004; 4(3):535-38. https:// doi.org/10.1111/j.1471-8286.2004.00684.x

- Wang J, Santiago E, Caballero A. Prediction and estimation of effective population size. Heredity. 2016; 117(4):193-206. https://doi.org/10.1038/ hdy.2016.43

- Waples RS. A bias correction for estimates of effective population size based on linkage disequilibrium at unlinked gene loci. Conserv Genet. 2006; 7(2):167-84. https://doi.org/10.1007/s10592-005-9100-y

- Waples RS, Antao T, Luikart G. Effects of overlapping generations on linkage disequilibrium estimates of effective population size. Genetics. 2014; 197(2):769-80. https://doi.org/10.1534/ genetics.114.164822
- Waples RS, Do C. Linkage disequilibrium estimates of contemporary Ne using highly variable genetic markers: A largely untapped resource for applied conservation and evolution. Evol Appl. 2010; 3(3):244-62. https://doi.org/10.1111/ j.1752-4571.2009.00104.x

- Waples RS, England PR. Estimating contemporary effective population size on the basis of linkage disequilibrium in the face of migration. Genetics. 2011; 189(2):633-44. https://doi.org/10.1534/ genetics.111.132233

- Zapata LA, Usma JS. Guía de las especies migratorias de la biodiversidad en Colombia. Peces. Volumen 2. Bogotá D.C.: Ministerio de Ambiente y Desarrollo Sostenible, WWF-Colombia; 2013.

\section{Neotropical Ichthyology}

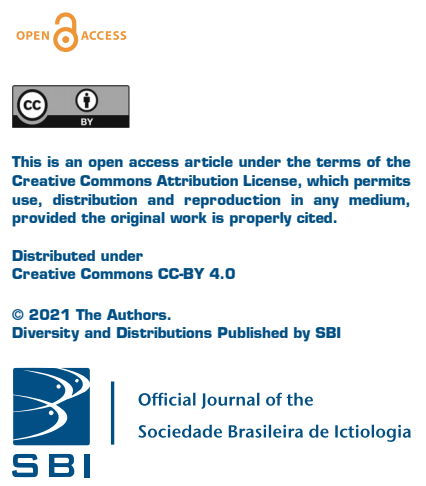

\section{AUTHOR'S CONTRIBUTION}

Kevin León García-Castro: Conceptualization, Data curation, Formal analysis, Investigation, Methodology, Software, Validation, Visualization, Writing-original draft, Writing-review and editing. José David Rangel-Medrano: Conceptualization, Data curation, Formal analysis, Investigation, Methodology, Validation, Visualization, Writing-original draft, Writing-review and editing. Ricardo Marcel Landínez-García: Conceptualization, Data curation, Formal analysis, Investigation, Methodology, Validation, Visualization, Writing-original draft, Writing-review and editing. Edna Judith Márquez: Conceptualization, Data curation, Formal analysis, Funding acquisition, Investigation, Methodology, Project administration, Resources, Software, Supervision, Validation, Visualization, Writing-original draft, Writing-review and editing.

\section{ETHICAL STATEMENT}

Environmental license number 0155-30/01/2009 from Ministerio de Ambiente, Vivienda y Desarrollo Territorial de Colombia.

\section{COMPETING INTERESTS}

The authors declare no competing interests.

\section{HOW TO CITE THIS ARTICLE}

- García-Castro KL, Rangel-Medrano JD, Landínez-García RM, Márquez EJ. Population genetics of the endangered catfish Pseudoplatystoma magdaleniatum (Siluriformes: Pimelodidae) based on species-specific microsatellite loci. Neotrop Ichthyol. 2021; 19(1):e200120. https://doi.org/10.1590/1982-0224-2020-0120 